\title{
Unjuk Kerja Mesin Pemanen Padi (Oryza sativa) Kombinasi Mini (Mini Combine Harvester)
}

\section{Performance of Mini Combine Paddy Harvester}

\author{
Mochamad Zakky $^{1}$, Joko Pitoyo ${ }^{2}$, Adi Prayoga ${ }^{3}$ \\ ${ }^{1}$ Program Studi Teknologi Mekanisasi Pertanian, Politeknik Enjiniring Pertanian Indonesia \\ ${ }^{2}$ Balai Besar Pengembangan Mekanisasi Pertanian, Kementerian Pertanian \\ ${ }^{3}$ Program Studi Tata Air Pertanian, Politeknik Enjiniring Pertanian Indonesia \\ 『Komunikasi Penulis, email: zakky141198@gmail.com \\ DOI:http://dx.doi.org/10.23960/jtep-l.v10i3.303-308
}

Naskah ini diterima pada 12 Juli 2021; revisi pada 20 Agustus 2021; disetujui untuk dipublikasikan pada 21 Agustus 2021

\begin{abstract}
Mini combine harvester is a modern machine used for cutting rice, threshing and cleaning grain while walking in the field. This machine helps farmers where, time and energy to harvest more efficiently and does not require a large amount of labor like traditional (manual) harvesting. This study aimed to calculate and determine the working capacity of the mini combine harvester machine and calculated the work efficiency of the mini combine harvester machine. The method used in this research was experimental using a mini combine harvester type Yanmar model YH150 with Ciherang 32 rice varieties ready to harvest. The results of this study indicated that the effective field capacity is $0.125 \mathrm{ha} / \mathrm{hour}$ or $8.028 \mathrm{hour} / \mathrm{ha}$, while the theoretical field capacity was $0.234 \mathrm{ha} / \mathrm{hour}$ so that the field efficiency is $53.23 \%$.
\end{abstract}

Keywords : field efficiency, field capacity, rice, mini combine harvester

\begin{abstract}
ABSTRAK
Alat dan mesin pemanen padi kombinasi mini (mini combine harvester) merupakan mesin modern yang digunakan untuk memotong padi, merontokkan dan membersihkan gabah sambil berjalan dilapangan. Mesin ini membantu petani karena, waktu dan tenaga untuk memanen lebih efisien dan tidak membutuhkan jumlah tenaga kerja yang besar seperti pemanenan tradisional (manual). Tujuan penelitian adalah untuk menghitung dan mengevaluasi kapasitas kerja mesin pemanen padi kombinasi mini dan menghitung efisiensi kerja mesin pemanen padi kombinasi mini. Penelitian dilakukan secara eksperimental dengan menguji mesin pemanen padi kombinasi mini (mini combine harvester) merek Yanmar model YH150 pada lahan padi varietas Ciherang 32 siap panen. Hasil penelitian ini menunjukkan kapasitas lapang efektif (KLE) sebesar 0,125 ha/jam atau 8,028 jam/ha, sedangkan kapasitas lapang teoritis (KLT) sebesar 0,234 ha/jam sehingga efisiensi lapangnya sebesar 53,23\%.
\end{abstract}

Kata Kunci: efiensi lapang, kapasitas lapang, mesin pemanen padi kombinasi mini, padi

\section{PENDAHULUAN}

Indonesia sebagai negara agraris memiliki lahan pertanian yang luas. Lahan-lahan pertanian ini banyak ditanami padi sebagai makanan pokok penduduk Indonesia. Seiring dengan meningkatnya taraf hidup masyarakat, maka tuntutan terhadap beras dengan kuantitas dan kualitas tinggi menjadi semakin meningkat. Menurut BPS (2021), luas panen padi tahun 2020 sebesar 10,66 juta hektar dengan produksi sebesar 54,65 juta ton Gabah Kering Giling (GKG). Jika dikonversikan menjadi beras, produksi beras pada 2020 mencapai 31,33 juta ton. Salah satu kegiatan yang mempengaruhi produksi padi adalah cara pemanenan, berbagai sistem telah dikembangkan dalam pemanenan padi, mulai alat potong padi tradisional (ani-ani), mesin potong padi (reaper dan binder), gebot padi, perontok padi (pedal thresher dan power thresher) dan 
yang modern mesin pemanen padi kombinasi (combine harvester). Beberapa permasalahan pada pemanen padi dengan cara tradisional (manual) adalah tenaga kerja yang berkurang dan kehilangan hasil, kehilangan pada pemanenan 9\% dan perontokan 5\% (Herawati et al., 2008).

Alat panen yang sering digunakan dalam memanen padi bermacam-macam, seperti menggunakan ani-ani, menggunakan arit biasa, arit bergerigi dan lain sebagainya. Dengan masuknya varietas unggul baru padi yang memiliki potensi hasil tinggi dan postur tubuh pendek, terjadi perubahan penggunaan alat panen dari ani-ani menjadi penggunaan aritbiasa dan penggunaan arit bergerigi. Pada pemanenan padi menggunakan mesin pemanen dapat menyebabkan kehilangan hasil yang lebih rendah. Cara memanen tergantung pada alat panen yang akan digunakan. Untuk varietas padi lokal dengan batang yang tinggi dan tahan rontok, biasanya alat panen sederhana ani-ani masih bisa digunakan petani untuk memanen padi dengan cara memotong tangkai malai. Pemanenan padi varietas unggul menggunakan sabit dapat dilakukan dengan memotong batang padi baik pada bagian atas, tengah, atau bawah menyesuaikan alat perontokan yang akan digunakan. Cara pemanenan tebang bawah umumnya dilakukan jika perontokannya dengan cara dibanting/ditebas atau dengan menggunakan mesin perontok padi (thresher) sedangkan panen padi dengan cara tebang atas dan tebang tengah dilakukan jika perontokan menggunakan mesin perontok (Setyono, 2010).

Lembaga-lembaga internasional telah mengembangkan mekanisasi pertanian cukup lama khususnya lembaga-lembaga yang berada di negara maju. Beberapa program pengembangan mekanisasi pertanian sukses, namun sebagian mengalami kegagalan. Menurut Hantoro (2020), faktor-faktor yang mempengaruhi keberhasilan dalam mengembangkan mekanisasi pertanian adalah kondisi iklim, sistem sosial, budaya, dan ekonomi masyarakat. Menurut Sulistiadji (2007), budi daya pertanian dibedakan menjadi 2, yaitu di lahan (on farm) kegiatan yang dilakukan di lahan mulai dari tanam hingga panen dan di luar lahan (off farm) kegiatan yang dilakukan di luar lahan seperti giling padi, dan lain sebagainya.
Salah satu mesin pemanen padi yaitu mesin pemanen padi kombinasi mini yang mempunyai fungsi memotong padi, merontokkan dan membersihkan gabah sambil berjalan di lapangan. Dengan fungsi tersebut, waktu dan tenaga untuk memanen lebih efisien dan tidak membutuhkan jumlah tenaga kerja yang besar seperti pemanenan tradisional (manual). Dari fungsi tersebut, alat dan mesin pemanen padi kombinasi mini ini memiliki kelebihan dari alat dan mesin panen lainnya yaitu menghemat biaya panen dan perontokan, mengurangi tenaga kerja, mempercepat operasi penyiapan lahan dapat untuk mengejar penanaman selanjutnya, pengelolaan jerami yang lebih terdistribusi di lahan, serta mempercepat proses pemasaran produksi atau gabah hasil panen. Di sisi lain, investasi yang besar merupakan salah satu kendala yang perlu diatasi dengan melibatkan lembaga dan instansi keuangan terkait (perbankan, kredit usaha rakyat, dan lain sebagainya) (Purba et al., 2015). Menurut Sutrisno (2007), secara umum kehilangan hasil (losses) terjadi mulai panen hingga penanganan pasca panen. Pada proses pemanenan di lahan terdapat kehilangan hasil sebesar $9-10,12 \%$ yaitu berupa gabah yang tercecer. Untuk menangani kehilangan hasil diperlukan teknologi tepat guna berupa mesin-mesin panen yang memiliki kapasitas dan efisiensi yang tinggi. Dari permasalahan tersebut, penelitian ini bertujuan untuk menghitung dan mengetahui kapasitas kerja mesin pemanen padi kombinasi mini dan menghitung efisiensi kerja mesin pemanen padi kombinasi mini.

\section{BAHAN DAN METODE}

Penelitian ini menggunakan mesin pemanen padi kombinasi (mini combine harvester) merek Yanmar model YH 150 dengan daya kerja 14,5 HP dan putaran 2.400 rpm seperti Gambar 1. Peralatan dan bahan yang digunakan adalah padi yang siap panen, bahan bakar solar, stopwatch, timbangan, pita ukur (meteran), karung (kantong) dan gelas ukur.

\subsection{Metode}

Penelitian ini menggunakan metoda eksperimental, yaitu dilaksanakan pada lahan padi sawah di Balai Penyuluhan Pertanian (BPP) 
Sepatan, Kabupaten Tangerang berada pada titik koordinat dengan $6^{\circ} 7^{\prime} 0,932$ "Lintang Selatan dan $106^{\circ} 35^{\prime} 3,162^{\prime \prime}$ Bujur Timur. Ukuran lahan yang digunakan berdimensi $45 \mathrm{~m}$ x 101,5 m. Luas keseluruhan lahan adalah $4.567,5 \mathrm{~m}^{2}$ terbagi menjadi 4 petakan sawah yaitu petakan $A$, petakan $\mathrm{B}$, petakan $\mathrm{C}$, dan petakan $\mathrm{D}$. Luas masing-masing petakan yaitu $1.080 \mathrm{~m}^{2}, 1.215 \mathrm{~m}^{2}$, $1.147,5 \mathrm{~m}^{2}$, dan $1.125 \mathrm{~m}^{2}$ (Gambar 2).

\subsection{Parameter yang Diamati}

Berdasarkan SNI 8185:2019 tentang mesin panen padi kombinasi yaitu syarat mutu dan metode uji terdapat pada Tabel 1 . Sebelum dilakukan analisis kapasitas lapang dan kapasitas kerja dilakukan pengumpulan data yaitu:

1. Luas lahan dihitung dengan menggunakan pita ukur (meteran),

2. Konsumsi bahan bakar minyak (BBM) dihitung dari volume BBM terpakai yang diukur menggunakan gelas ukur setelah pengoperasian di setiap petak,

3. Hasil panen setiap kegiatan pemanenan pada masing-masing petakan diukur dengan menggunakan timbangan,

4. Waktu Pemanenan diukur dengan menggunakan stopwatch di setiap petak lahan, di mulai mesin berjalan hingga akhir mesin memanen,

5. Kecepatan diukur dengan keliling lahan dibagi waktu tempuh.

6. Lebar kerja diukur dengan menggunakan meteran.

\subsubsection{Kapasitas Lapang Pemanenan}

Untuk mengetahui unjuk kerja mesin pemanen padi kombinasi mini, perlu diketahui kapasitas lapang. Kapasitas lapang pemanenan dibagi menjadi 2 yaitu kapasitas lapang efektif pemanenan (KLE) dan kapasitas lapang teoritis pemanenan (KLT). Kapasitas lapang efektif pemanenan (KLE) adalah perbandingan antara kebutuhan (total) waktu operasi mesin untuk menyelesaikan pekerjaan pemanenan dengan luasan lahan (Hadiutomo, 2012). Persamaan untuk menghitung kapasitas lapang efektif pemanenan dapat dihitung dengan Persamaan 1 adalah:

$$
K L E=\frac{A}{t}
$$

dimana, KLE adalah kapasitas lapang efektif pemanenan (ha/jam), A adalah luas lahan yang dipanen (ha), dan $t$ adalah total waktu operasi (jam).

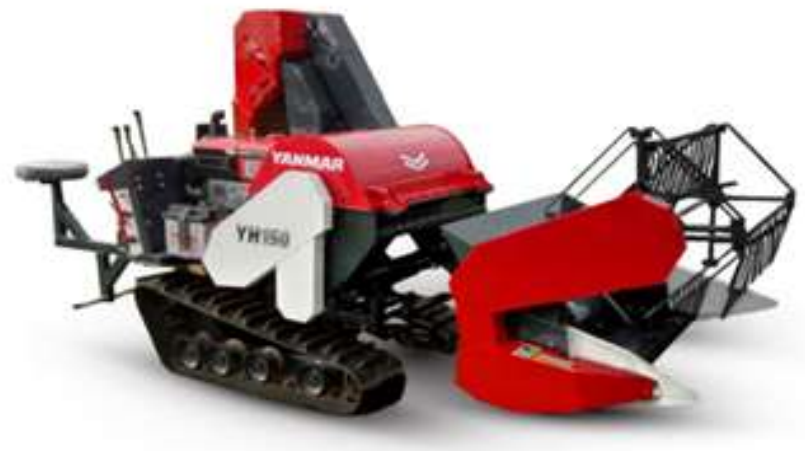

Gambar 1. Mesin Pemanen Padi Kombinasi YH 150 Merek Yanmar (Balai Besar Pengembangan Mekanisasi Pertanian, 2018)
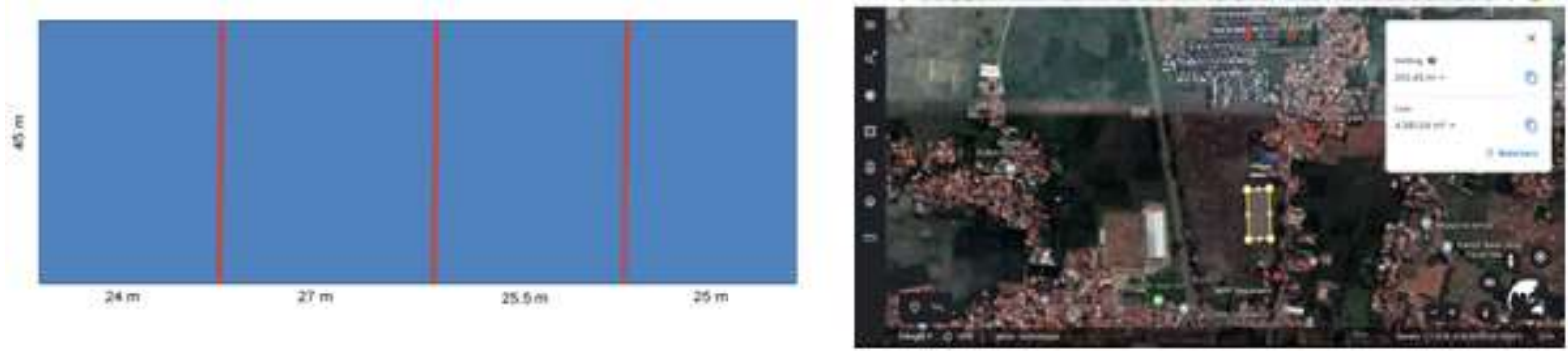

Gambar 2. Lokasi Penelitian 
Tabel 1. Mesin Panen Padi Kombinasi Mini

\begin{tabular}{lcc}
\hline \multicolumn{1}{c}{ Parameter } & Satuan & SNI \\
\hline Kecepatan Jalan Pemanenan & $\mathrm{km} / \mathrm{jam}$ & $1,0-3,0$ \\
Kapasitas Lapang Efektif & $\mathrm{ha} / \mathrm{jam}$ & Min. 0,10 \\
& jam/ha & - \\
Efisiensi Lapang Pemanenan & $\%$ & Min. 50 \\
Konsumsi Bahan Bakar & $\mathrm{l} / \mathrm{jam}$ & Maks. 2,5 \\
\hline Sumber: BSN, SNI 8185:2019 & &
\end{tabular}

Perhitungan kapasitas lapang teoritis pemanenan (KLT) merupakan perhitungan kapasitas lapang dengan mengukur lebar kerja alsin dan kecepatan kerja (Hadiutomo, 2012). Kapasitas lapang teoritis pemanenan (KLT) dihitung menggunakan Persamaan 2 adalah:

$$
K L T=0,36 * w t * v t
$$

dimana, KLT adalah kapasitas lapang teoritis pemanenan (ha/jam), 0,36 adalah faktor konversi, wt adalah lebar kerja teoritis (m), dan vt adalah kecepatan maju teoritis (m/detik).

\subsubsection{Efisiensi Lapang Pemanenan}

Efisiensi lapang adalah perbandingan antara kapasitas lapang efektif pemanenan (KLE) dengan kapasitas lapang teoritis pemanenan (KLT) dan dinyatakan dalam persentase (\%) (Hadiutomo, 2012). Untuk menghitung efisiensi lapang mesin pemanen padi kombinasi mini digunakan Persamaan 3 sebagai berikut:

$$
\eta=\frac{K L E}{K L T} * 100 \%
$$

dimana, $\eta$ adalah efisiensi lapang pemanenan (\%), KLE adalah kapasitas lapang efektif pemanenan (ha/jam), dan KLT kapasitas lapang teoritis pemanenan (ha/jam).

\subsubsection{Konsumsi Bahan Bakar}

Bahan bakar yang digunakan pada mesin pemanen padi kombinasi mini adalah solar, adapun penggunaan bahan bakar diukur dengan menggunakan gelas ukur. Konsumsi bahan bakar merupakan perbandingan antara penggunaan bahan bakar (liter) dengan waktu operasi pemanenan (jam) (Hadiutomo, 2012). Untuk menghitung konsumsi bahan bakar alsin pemanen padi kombinasi mini digunakan Persamaan 4 sebagai berikut:

$$
F C=\frac{F V}{t}
$$

dimana, FC adalah konsumsi bahan bakar (l/ jam), FV adalah volume bahan bakar terpakai (l), dan t adalah waktu operasi pemanenan (jam).

\section{HASIL DAN PEMBAHASAN}

Penelitian ini menggunakan Mesin pemanen padi kombinasi mini merek Yanmar model YH 150 dengan varietas padi Ciherang 32, pola tanam jarwo $2: 1$, jarak tanam $30: 60$, jarak tanam dalam baris $15 \mathrm{~cm}$, dan umur tanaman saat panen 110 HST. Kecepatan yang digunakan pada penelitian ini adalah $0,5 \mathrm{~m} /$ det atau setara 1,8 $\mathrm{km} / \mathrm{jam}$ dan lebar kerja $1300 \mathrm{~mm}$ atau 1,3 m. Adapun hasil pengumpulan data dapat dilihat pada Tabel 2.

Tabel 2 menunjukkan bahwa hasil gabah $2.719,30 \mathrm{~kg}$ atau 2,719 ton dengan luas lahan $4.567,5 \mathrm{~m}^{2}$ atau dikonversi 1 ha menjadi $5.953,59 \mathrm{~kg}$ atau 5,95 ton/ha. Menurut BPS Kabupaten Tangerang (2021), produktivitas padi di Kabupaten Tangerang sebesar 4,84 ton/ ha pada tahun 2020 sehingga hasil dari penelitian ini di atas rata-rata produktivitas Kabupaten Tangerang. Hasil ini lebih tinggi dikarenakan dilakukan secara intensif yaitu pemilihan benih unggul, pemupukan yang presisi, dan menggunakan alat dan mesin pertanian dari mulai pengolahan tanah mengggunakan traktor roda 2 , penanaman menggunakan walking transplanter, pemupukan menggunakan drone, dan pemanenan menggunakan mini combine harvester. Dari hasil pengumpulan data tersebut, maka dapat dihitung kapasitas lapang efektif pemanenan (KLE), kapasitas lapang teoritis pemanenan (KLT) dan efisiensi lapang pemanenan ( $\mathrm{\eta}$ ) Hasil dari penghitungan dapat dilihat pada Tabel 3.

Dari Tabel 3 untuk rata-rata kapasitas lapang efektif pemanenan (KLE) sebesar 0,125 ha/jam atau $8,028 \mathrm{jam} / \mathrm{ha}$. Sedangkan untuk kapasitas lapang teoritis pemanenan (KLT) adalah 0,234 ha/jam sehingga efisiensi lapang pemanenan untuk alsin pemanen padi kombinasi mini sebesar $53,234 \%$, sedangkan rata-rata konsumsi 
Tabel 2. Hasil Pengumpulan Data

\begin{tabular}{cccccc}
\hline Petak & $\begin{array}{c}\text { Luas Lahan } \\
\mathbf{( m}^{\mathbf{2}} \mathbf{)}\end{array}$ & $\begin{array}{c}\text { Hasil Gabah } \\
\mathbf{( k g )}\end{array}$ & $\begin{array}{c}\text { Konsum si BBM } \\
\mathbf{( m )}\end{array}$ & $\begin{array}{c}\text { Waktu } \\
\text { (menit) }\end{array}$ & $\begin{array}{c}\text { Waktu } \\
\text { (jam) }\end{array}$ \\
\hline A & $1.080,00$ & 824,00 & $1.685,0$ & 55,0 & 0,92 \\
B & $1.215,00$ & 661,40 & $1.685,0$ & 57,0 & 0,95 \\
C & $1.147,50$ & 646,52 & $1.880,0$ & 55,0 & 0,92 \\
D & $1.125,00$ & 587,38 & $1.720,0$ & 53,0 & 0,88 \\
\hline Rerata & $\mathbf{1 . 1 4 1 , 8 8}$ & $\mathbf{6 7 9 , 8 3}$ & $\mathbf{1 . 7 4 2 , 5}$ & $\mathbf{5 5 , 0}$ & $\mathbf{0 , 9 2}$ \\
\hline
\end{tabular}

Tabel 3. Penghitungan Kapasitas Lapang, Efisiensi Lapang, dan Konsumi Bahan Bakar

\begin{tabular}{|c|c|c|c|c|c|}
\hline \multirow{2}{*}{ Petak } & \multicolumn{2}{|c|}{ KLE } & \multirow{2}{*}{$\begin{array}{c}\text { KLT } \\
\text { (ha/jam) }\end{array}$} & \multirow{2}{*}{$\begin{array}{c}\eta \\
(\%)\end{array}$} & \multirow{2}{*}{$\begin{array}{c}\text { Konsumsi BBM } \\
(1 / \text { jam })\end{array}$} \\
\hline & (ha/jam) & (jam/ha) & & & \\
\hline A & 0,118 & 8,488 & 0,234 & 50,43 & 1,838 \\
\hline B & 0,128 & 7,819 & 0,234 & 54,70 & 1,774 \\
\hline $\mathrm{C}$ & 0,125 & 7,988 & 0,234 & 53,42 & 2,051 \\
\hline $\mathrm{D}$ & 0,127 & 7,852 & 0,234 & 54,27 & 1,947 \\
\hline Rerata & 0,125 & 8,028 & 0,234 & 53,42 & 1,901 \\
\hline
\end{tabular}

bahan bakar sebesar 1,901 l/jam. Hasil ini lebih baik dari SNI 8185:2019, dimana pada SNI efisiensi 50\%. Mini combine harvester memiliki efisiensi yang tinggi karena bentuknya yang kecil sehingga memudahkan untuk manuver dilahan sempit seperti lahan dilokasi penelitian. Pada Mesin pemanen padi kombinasi mini merek Yanmar model YH 150 mempunyai daya mesin $14 \mathrm{HP}$, apabila ingin ditingkatkan efisiensi dapat menambah daya mesin tersebut Hasil penelitian ini tidak jauh berbeda dengan penelitian lain mengenai unjuk kerja mesin pemanen kombinasi mini. Pada ujicoba mesin panen padi kombinasi (combine harvester) di lahan pasang surut Provinsi Kalimantan Selatan dihasilkan kapasitas kerja efektif sebesar 7,87 ha/jam dengan efisiensi kerja sebesar 63,59\% (Pangaribuan, et. al. 2017). Sedangkan menurut Sulistiadji (2008), untuk Stripper tipe Riding mempunyai kapasitas kerja lapang 2,5-4,2 jam/ ha dan efisiensi kerja lapang 52,52\%, stripper tipe walking mempunyai kapasitas kerja lapang 7,5 jam/ha dan efisiensi kerja 80\%, Mesin sabit mower mempunyai kapasitas kerja lapang 18 jam/ha dan efisiensi kerja 95,5\%. Aplikasi mesin pemanen padi kombinasi mini tipe jajar legowo di Kabupaten Pinrang, Sulawesi Selatan, menunjukkan kapasitas lapang efektif sebesar 8,33 jam/ha. Perbedaan kapasitas kerja mungkin disebabkan oleh beberapa faktor yang mempengaruhi unjuk kerja alsin pemanen padi kombinasi mini, seperti kondisi lahan (tanah) berlumpur, sehingga alsin berjalan dengan lambat, kondisi tanaman padi yang berembun (berair) sehingga bulir padi banyak yang menempel di bagian perontok, kemahiran operator dan pembantu (helper) dalam melakukan manuver di areal persawahan.

\section{KESIMPULAN}

Unjuk kerja mesin pemanen padi kombinasi mini (mini combine harvester) merek Yanmar dengan model YH150 yang digunakan pada penelitian pemanenan padi di BPP Sepatan, Kabupaten Tangerang dengan lebar kerja $1300 \mathrm{~mm}$ atau 1,3 $\mathrm{m}$, kecepatan rata-rata $1,8 \mathrm{~km} / \mathrm{jam}$ atau $0,5 \mathrm{~m} /$ det, luas lahan $4567,50 \mathrm{~m}^{2}$, konsumsi BBM ratarata 1,901 l/jam, jumlah gabah kering panen (GKP) sebesar $2719,30 \mathrm{~kg}$, dan waktu pengoperasian rata-rata 55 menit. Pada penelitian ini menghasilkan kapasitas lapang efektif pemanenan (KLE) sebesar 0,125 jam/ha atau 8,028 ha/jam, sedangkan kapasitas lapang teoritis pemanenan (KLT) sebesar 0,234 jam/ ha. Dari hasil penelitian tersebut, menghasilkan efisiensi lapang pemanenan 53,234\%.

\section{UCAPAN TERIMA KASIH}

Ucapan terima kasih disampaikan kepada BPP Sepatan, Kabupaten Tangerang yang telah 
memberikan fasilitas penggunaan lahan untuk kegiatan ini dan Balai Besar Pengembangan Mekanisasi Pertanian, dan PT. Yanmar yang telah memfasilitasi alat dan mesin pemanen, serta kepada pimpinan dan teman-teman Politeknik Enjiniring Pertanian Indonesia.

\section{DAFTAR PUSTAKA}

Badan Pusat Statistik (BPS). 2021. Berita Resmi Statistik, Luas Panen dan Produksi Padi di Indonesia 2020 (angka tetap). No. 22/03/ Th. XXIV, 1 Maret 2021. Jakarta. 20 hal.

Badan Pusat Statistik (BPS). 2021. Kabupaten Tangerang Dalam Angka 2021. Tangerang. 450 hal.

Badan Standardisasi Nasional (BSN). 2019. Mesin panen padi kombinasi (paddy combine harvester) - Syarat mutu dan metode uji menurut SNI 8185:2019. Jakarta. 25 hal.

Balai Besar Pengembangan Mekanisasi Pertanian. 2018. Laporan Hasil Pengujian Mesin Panen Padi Kombinasi (Paddy Combine Harvester). Nomor Test Report: L B. 130 / 233 / M P P / 12 / X/ 2018. Kabupaten Tangerang. 11 hal.

Hadiutomo, K. 2012. Mekanisasi Pertanian. IPB Press. Bogor. 460 hal.

Hantoro, F.R.P., Prasetyo, E., dan Hermawan, A. 2020. Dampak Penggunaan Alat dan Mesin Pertanian terhadap Produksi Padi di Kabupaten Tegal. Pangan, 29(3): 171180.

Herawati, H. 2008. Mekanisme dan Kinerja pada Sistem Perontokan Padi. Prosiding
Seminar Nasional Teknik Pertanian 2008. Yogyakarta. 13 hal.

Salim, I., Jafar, Y., dan Sapsal, T. 2021. Unjuk Kerja Rice Transplanter Sistem Jajar Legowo Tipe Crown Indo Jarwo Di Kabupaten Pinrang Sulawesi Selatan. Jurnal Teknik Pertanian Lampung, 10(1): 113-118,

Pangaribuan, S., Umar, S., Suprapto, A., Harmanto. 2017. Uji Coba Mesin Panen Padi (Combine Harvester) Di Lahan Pasang Surut. Prosiding Seminar Nasional Pengembangan Teknologi Pertanian. Politeknik Negeri Lampung: 103-109.

Purba, T. Anshori, D. Suheiti, K. 2015. Inovasi Teknologi Mesin Panen Mini Combine Harvester Mendukung Penanganan Panen dan Pascapanen Padi di Kalimantan Barat. Pusat Perpustakaan dan Penyebaran Teknologi Pertanian. Bogor: 1382-1386.

Setyono, A. 2010. Perbaikan Teknologi Pascapanen dalam Upaya Menekan Kehilangan Hasil Padi. Pengembangan Inovasi Pertanian, 3(3): 212-216.

Sulistiadji, K. 2007. Alat dan Mesin (Alsin) Panen dan Perontokan Padi di Indonesia. Balai Besar Pengembangan Mekanisasi Pertanian. Serpong. 44 hal.

Sulistiadji, K. Rosmeika, Gunanto, A. 2008. Evaluasi Kinerja Mesin Panen Padi Pada Lahan Pasang Surut. Jurnal Enjiniring Pertanian, VI(1): 13-22.

Sutrisno. 2007. Penanganan Pasca Panen Padi di Indonesia. Jurnal Keteknikan Pertanian, 21(2): 105-114. 